\title{
The gustatory competence of the lingual epithelium requires neonatal innervation
}

\author{
Bruce Oakley \\ Department of Biology, Unitersity of Michigan, Ann Arbor, MI 48109-1048 (USA)
}

(Accepted 3 November 1992)

Key words: Development; Embryonic: Glossopharyngeal nerve; Induction; Neurotrophic; Stem cell: Taste

\begin{abstract}
The rat vallate papilla is bilaterally innervated by the IXth nerve whose axons are required for the normat development of its several hundred taste buds. Temporary denervation during the developmental sensitive period for taste buds prevented most vallate taste buds from forming. Specifically, removing one IXth nerve and crushing the other in 3 day old neonates eliminated axons from the vallate papilla for about 10 days and by adulthood resulted in a mean \pm 1 S.E.M. of $48 \pm 12$ vallate taste buds. Two explanations for the shortfall of adult vallate taste buds were evaluated: either 10 days of neonatal denervation impaired the gustatory competence of the vallate papilla. or the IXth nerve's trophic support of taste buds failed to recover after nerve crush on day 3 . In adults, it was found that a IXth nerve previously crushed on day 3 would support numerous vallate taste buds $(183 \pm 27$, provided that the vallate papilla had been continuously innervated by the contralateral IXth nerve during neonatal development. Consequently, taste neurons, whose axons had been crushed on day 3 . seemed to survive and retain their trophic capacity to support taste buds in adults. To test for diminished competence of the gustatory epithelium, one IXth nerve was crushed on day 3 while the contralateral IXth nerve was removed. Beginning on day 75 , the chorda tympani nerve was substituted for the re-innervating axons of the crushed IXth nerve. The cross-innervating chorda tympani ultimately supported only $51 \pm 10$ vallate taste buds. In contrast. in vallate papillate that developed without interruption of the contralateral IXth nerve during the sensitive period, the cross-innervating chorda tympani by itself supported more than four times as many vallate taste buds $(214 \pm 22)$. Evidently, a neonatal period of denervation permanently restricts the gustatory competence of the vallate epithelium; nerve-dependent precursors of taste receptor cells probably died or gpermanently changed their fate.
\end{abstract}

\section{INTRODUCTION}

It has been recognized for more than a century that adult mammalian taste buds are nerve-dependent denervated taste buds degenerate, yet readily re-form if fungiform, foliate or vallate papillae are subsequently re-innervated ${ }^{11}$. In contrast, the development ${ }^{3}$ and maintenance of the tongue's filiform papillae does not require innervation. However, it has been shown recently that gustatory innervation can negatively regulate filiform spine outgrowth ${ }^{15}$. An ectopic filiform spine will grow and extend from the apical surface of a denervated adult fungiform papilla ${ }^{15}$. Hence, in adults, re-innervation by gustatory axons not only re-forms the fungiform taste bud, but also suppresses the morphogenetic program for a filiform spine. Neuronal-epithelial interactions affecting the development of taste buds need to be further examined. The present study focuses on the gustatory nerve dependency of the developing vallate papilla of rat.

On the midline of the tongue of albino rats lies a single vallate papilla consisting of a $1-\mathrm{mm}$ diameter island of tissue nearly surrounded by an elliptical trench whose walls are innervated by both the right and left IXth nerves. Vallate taste buds mature postnatally, as there are no mature vallate taste buds at birth in rat or hamster 4.9 .17 . The full complement of about 600 vallate taste buds is not attained until rats are about 3 months old. Within the day $10-45$ post-partum period, a given taste bud requires about 10 days to mature, i.e. form a taste pore ${ }^{16}$. In development vallate taste buds are neurally induced ${ }^{5}$ during a sensitive period that is maximal from day $0-10$ post-partum ${ }^{6}$. After avulsion of one IXth nerve on day 3. a mean \pm 1 S.E.M. of

Correspondence: B. Oakley. Department of Biology, 3127 Natural Science Building. University of Michigan. Ann Arbor. MI 48109-1048. USA. Fax: (1) (313) 747-0884. 
$228 \pm 10$ vallate taste developed, rather than the $496 \pm$ 22 taste buds that one IXth nerve will support in adults. Removing one IXth nerve while crushing the other on day 3 led to an even more profound shortfall of vallate taste buds. Even though axons from the crushed IXth nerve began to re-invade the gustatory epithelium by day 13, the period of denervation from day 3-13 caused a conspicuous shortfall of taste buds fewer than 50 taste buds developed by day $90^{5,6}$.

The primary experimental objective of the present investigation was to determine whether the shortfall of vallate taste buds after temporary neonatal denervation could be reversed by other taste axons or whether it reflected a permanent developmental impairment of the vallate papilla. Since neonatal nerve crush can eliminate interactions between gustatory axons and the epithelium for about 10 days, this treatment might not only diminish the competence of vallate cells to form taste buds, but might also diminish the regenerated IXth nerve's capacity to induce taste buds in development or diminish the IXth nerve's capacity to support taste buds trophically in adults. Cross-innervation in adults was used to evaluate both the gustatory competence of the neonatally denervated vallate papilla and the inductive and trophic capacities of a neonatally crushed IXth nerve. It was hypothesized that temporary bilateral denervation during the sensitive period would permanently diminish the gustatory competence of the vallate epithelium.

\section{MATERIALS AND METHODS}

\section{Surgical procedures}

Sprague-Dawley albino rats Rattus norvegicus (obtained from Harlan Co., Indianapolis, IN, USA) were used to study the effects of neonatal interruption of the IXth (glossopharyngeal) nerve supply to the circumvallate papilla. Anesthesia was induced with ether masks for 3-day-old neonates or with sodium pentobarbital i.p. $(5 \mathrm{mg} / \mathrm{kg}$ ). combined with ketamine-HCl, $125 \mathrm{mg} / \mathrm{kg}$ body weight $\mathrm{im}$. for adults. Adults also received a $50,000 \mathrm{U} / \mathrm{kg}$ i.m. injection of Bicillin antibiotic $12-24 \mathrm{~h}$ prior to surgery.

The IXth nerve was crushed immediately proximal to its pharyngeal branch by pinching it 10 times with the tips of fine forceps. followed by visual inspection to verify that this procedure had crushed but not transected the IXth nerve. Nerve avulsion consisted of using forceps to remove much of the IXth nerve between the petrosal ganglion and tongue. These operations did not seriously impair feeding, as neonates began to suckle within $4-8 \mathrm{~h}$ and adult animals were eating and drinking normally by the second postoperative day.

Cross-innervation of the adult tongue ${ }^{10}$ was aided by using a nerve splice, removed from the ipsilateral mylohyoid $(\mathrm{MH})$ nerve, to join the severed ends of the chorda tympani (CT) and IXth nerves. (The CT nerve supplies taste fibers to the fungiform papillae located in the anterior two-thirds of the rat tongue. It does not innervate the vallate papilla, which is exclusively and bilaterally innervated by the IXth nerve in normal rats.) A single 11-0 nylon suture (Ethicon Co.) was used to join the opposed nerve ends at each junction between the MH splice and the taste nerves (Fig. 1).

Nine groups of operated animals were used to evaluate whether neonatal denervation diminished the gustatory competence of the vallate epithelium or eliminated the capacity of the IXth nerve to induce or trophically support taste buds. Seven of these groups underwent two-stage operations (days 3 and 75). Table 1 indicates the various operative procedures, their timing, and the number of animals in each group. In groups $1-6$, the left IXth nerve was avulsed (AV) on day 3 or day 75 and the right IXth nerve crushed (CR) on day 3 . In group 1 , the vallate papilla must have lacked IXth nerve axons for about 10 days, since it has been shown ${ }^{6}$ that axons crushed on day 3 reappear in the epithelium beginning about day 13 . On day 75 control self-reconnection was made (group 3) or experimental nerve crosses were made between the normal chorda tympani and the neonatally crushed IXth nerve (groups 4-7). The left IXth nerve was sham crushed (exposed but not manipulated) in groups 7 and 8 . Animals were euthanized between 170 and 270 days of age, except those in group 8 which were euthanized between 290 and 385 days of age.

\section{Histological procedures}

Animals were deeply anesthetized with an i.p. injection of sodium pentobarbital. An infusion pump was used to perfuse the anes-

\section{TABLE 1}

\section{Methods: nerce operations}

AV, avulsion of a IXth nerve on day 3 or $75 ; \mathrm{CR}$, crush of a IXth nerve on day 3 or $75 ; \mathrm{CT}$, chorda tympani nerve; MH, mylohyoid nerve.

\begin{tabular}{|c|c|c|c|c|c|c|}
\hline \multicolumn{7}{|c|}{ (A) Operations to evaluate the vallate papilla } \\
\hline \multirow[t]{2}{*}{ Group } & & \multirow{2}{*}{\multicolumn{4}{|c|}{$\frac{\text { Day of nerve operations }}{\text { Day } 3}$}} & \multirow[t]{2}{*}{ Number of rats } \\
\hline & & & & & & \\
\hline 1 & & \multicolumn{2}{|c|}{$\mathrm{AV} 3 / \mathrm{CR} 3$} & \multicolumn{2}{|c|}{-} & 10 \\
\hline 2 & & \multicolumn{2}{|c|}{ SHAM $/$ CR3 } & \multicolumn{2}{|c|}{ AV75/CR3 } & 7 \\
\hline 3 & & \multicolumn{2}{|c|}{ SHAM $/$ CR 3} & \multicolumn{2}{|c|}{ AV75/CR3-MH-CR3 } & 5 \\
\hline 4 & & \multicolumn{2}{|c|}{$\mathrm{AV} 3 / \mathrm{CR} 3$} & \multicolumn{2}{|c|}{$\mathrm{AV} 3 / \mathrm{CT}-\mathrm{MH}-\mathrm{CR} 3$} & 8 \\
\hline 5 & & \multicolumn{2}{|c|}{$\mathrm{SHAM} / \mathrm{CR} 3$} & \multicolumn{2}{|c|}{ AV75/CT-MH-CR3 } & 7 \\
\hline \multicolumn{7}{|c|}{ (B) Operations to evaluate the IXth nerve } \\
\hline \multirow[t]{2}{*}{ Group } & \multicolumn{5}{|c|}{ Day of nerve operations } & \multirow[t]{2}{*}{ Number of rat } \\
\hline & \multicolumn{2}{|c|}{$\overline{\text { Day } 3}$} & \multicolumn{2}{|l|}{ Day 75} & Day 180 & \\
\hline 6 & \multirow{2}{*}{\multicolumn{2}{|c|}{$\begin{array}{l}\text { AV3/CR3 } \\
\text { SHAM/CR3 }\end{array}$}} & \multirow{2}{*}{\multicolumn{2}{|c|}{$\begin{array}{l}\mathrm{AV} 3 / \mathrm{CR} 3-\mathrm{MH}-\mathrm{CT} \\
\mathrm{SHAM} / \mathrm{CR} 3-\mathrm{MH}-\mathrm{CT}\end{array}$}} & - & 10 \\
\hline 7 & & & & & - & 4 \\
\hline 8 & \multicolumn{2}{|c|}{-} & \multicolumn{2}{|c|}{ SHAM/CR75 } & $\mathrm{SHAM} / \mathrm{CR} 75-\mathrm{MH}-\mathrm{CT}$ & 7 \\
\hline 9 & \multicolumn{2}{|l|}{-} & \multicolumn{2}{|l|}{ CT AVULSION } & - & 5 \\
\hline
\end{tabular}


thetized animals intracardially with $250 \mathrm{ml}$ of buffered $0.9 \% \mathrm{NaCl}$ (pH 7.4) containing $0.02 \%$ heparin and $0.5 \%$ procaine- $\mathrm{HCl}$, followed by a $250-\mathrm{ml}$ mixture of $4 \%$ formaldehyde, $1 \% \mathrm{NH}_{4} \mathrm{OH}$ and $15 \%$ sucrose, final concentrations.

Serial, $10-\mu \mathrm{m}$ transverse sections of paraffin embedded tongues of 64 rats were stained with Heidenhain's iron hematoxylin. Vallate taste buds were counted in normal animals at 90 and 180-225 days of age. The counts of fungiform taste buds were derived from examination of serial sections of the entire anterior portion of each animal's tongue from the tip to the dorsal median eminence.

\section{RESULTS}

Normal Sprague-Dawley rats have $573 \pm 40$ (mean \pm 1 S.E.M.) vallate taste buds at 180 days of $\mathrm{age}^{4}$. As shown previously, avulsing one IXth nerve and crushing the other on day 3 (AV3/CR3) temporarily denervates the vallate papilla during much of the developmental sensitive period and markedly reduces the number of taste buds that develop ${ }^{5.6}$. These results were replicated in the present experiment; CR3 IXth nerves supported a mean of $48 \pm 12$ taste buds in adults. Can this shortage of taste buds be attributed to the death of taste neurons having crushed axons or to barriers that regenerating axons encounter in navigating through the distal stump of a crushed nerve? Provided that the

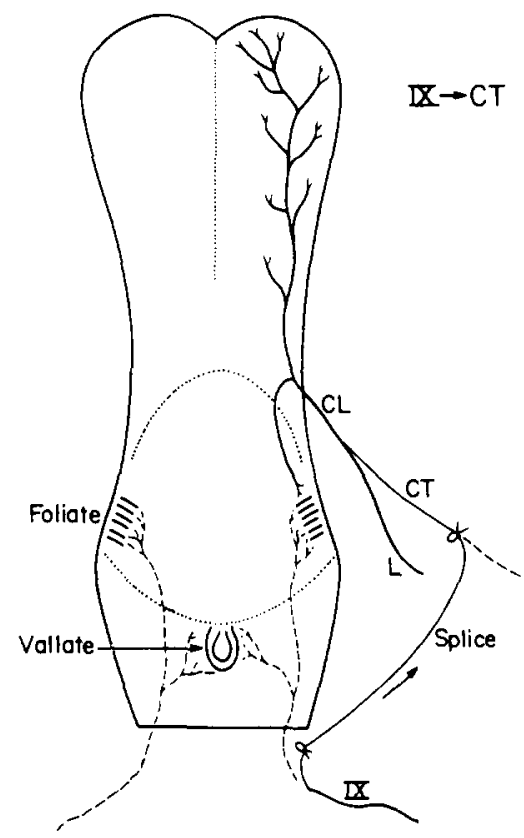

Fig. 1. A schematic drawing of the sensory innervation of the rat tongue depicts how the proximal portion of the transected IXth nerve was connected via a splice of the MH nerve to the distal stump of the CT nerve. The distal portions of right IXth nerve and the proximal portion of the right CT nerve were avulsed (dashed lines on the right side). In the animals whose proximal CT was connected via a MH splice to the distal stump of the IXth nerve (not shown), the left IXth nerve was also removed (dashed line on the left side). L, intact lingual nerve; $\mathrm{CL}$, combined chorda-lingual nerve. The tongue is about $2 \mathrm{~cm}$ long.

\section{TABLE II}

Early deneriation and taste bud induction

For simplicity only, the final status of the gustatory nerves is given under operative status. Abbreviations as in Table I.

\begin{tabular}{llcl}
\hline Group & Operative status & $\begin{array}{l}\text { Vallate } \\
\text { (mean } \pm I \text { S.E.M.) }\end{array}$ & Fungiform \\
\hline- & Normal vallate & $573 \pm 40(n=11)$ & - \\
1 & AV3/CR3 & $48 \pm 12(n=10)$ & - \\
2 & AV75/CR3 & $183 \pm 27(n=7)$ & - \\
3 & AV75/CR3-CR3 & $173 \pm 23(n=5)$ & - \\
4 & AV3/CT-CR3 & $51 \pm 10(n=8)$ & - \\
5 & AV75/CT-CR3 & $214 \pm 22(n=7)$ & - \\
& \multicolumn{4}{c}{$p<0.001(214 \mathrm{vs.51)}$} \\
- & Normal fungiform & - & $82 \pm 2(n=22)$ \\
6 & AV3/CR3-CT & - & $57 \pm 4(n=10)$ \\
7 & SHAM/CR3-CT - & $66 \pm 6(n=4)$ \\
8 & SHAM/CR75-CT & $6.3 \pm 6(n=7)$ \\
9 & Control CT avulsion - & $17 \pm 4(n=5)$ \\
\hline
\end{tabular}

vallate papilla had been continuously innervated by one IXth nerve until day 75 , the CR3 nerve alone sustained numerous vallate taste buds in adults ( $183 \pm$ 27). Even after the CR3 nerve was required to regenerate a second time, it supported numerous vallate taste buds in adults $(173 \pm 23$; compare groups $1-3$ in Table II). Hence, factors other than the death of damaged taste neurons or an obstructed nerve conduit must have been responsible for the limited number of taste buds. To test for diminished vallate gustatory competence in adults, nerve anastomosis was used to direct chorda tympani taste fibers into a vallate papilla that had previously been temporarily denervated in neonates. Axons of the cross-innervating CT supported no more vallate taste buds $(51 \pm 10$; Fig. $2 \mathrm{~B}$ and group 4 in Table II) than a CR3 nerve after temporary neonatal denervation (group 1 in Table II). In contrast. in a continuously innervated control vallate papilla (only one IXth nerve had been interrupted on day 3). the cross-innervating CT nerve alone supported more than four times as many adult vallate taste buds ( 214 vs. 51 buds, $P<0.001, t$ test; group 5 in Table II; Fig. 2A).

To evaluate whether the trophic capacity of adult IXth nerves required interaction between its axons and the gustatory epithelium during the sensitive period, CR3 nerves were sutured to the distal stump of the normal CT on day 75. CR3 nerves associated with neonatally denervated vallate papillae re-formed $57 \pm 4$ fungiform taste buds when directed to the front of the adult tongue (Table II). CR3 nerves associated with vallate papillae that had been continuously innervated by the contralateral IXth nerve reformed $66 \pm 6$ fungiform taste buds when directed to the front of the adult 

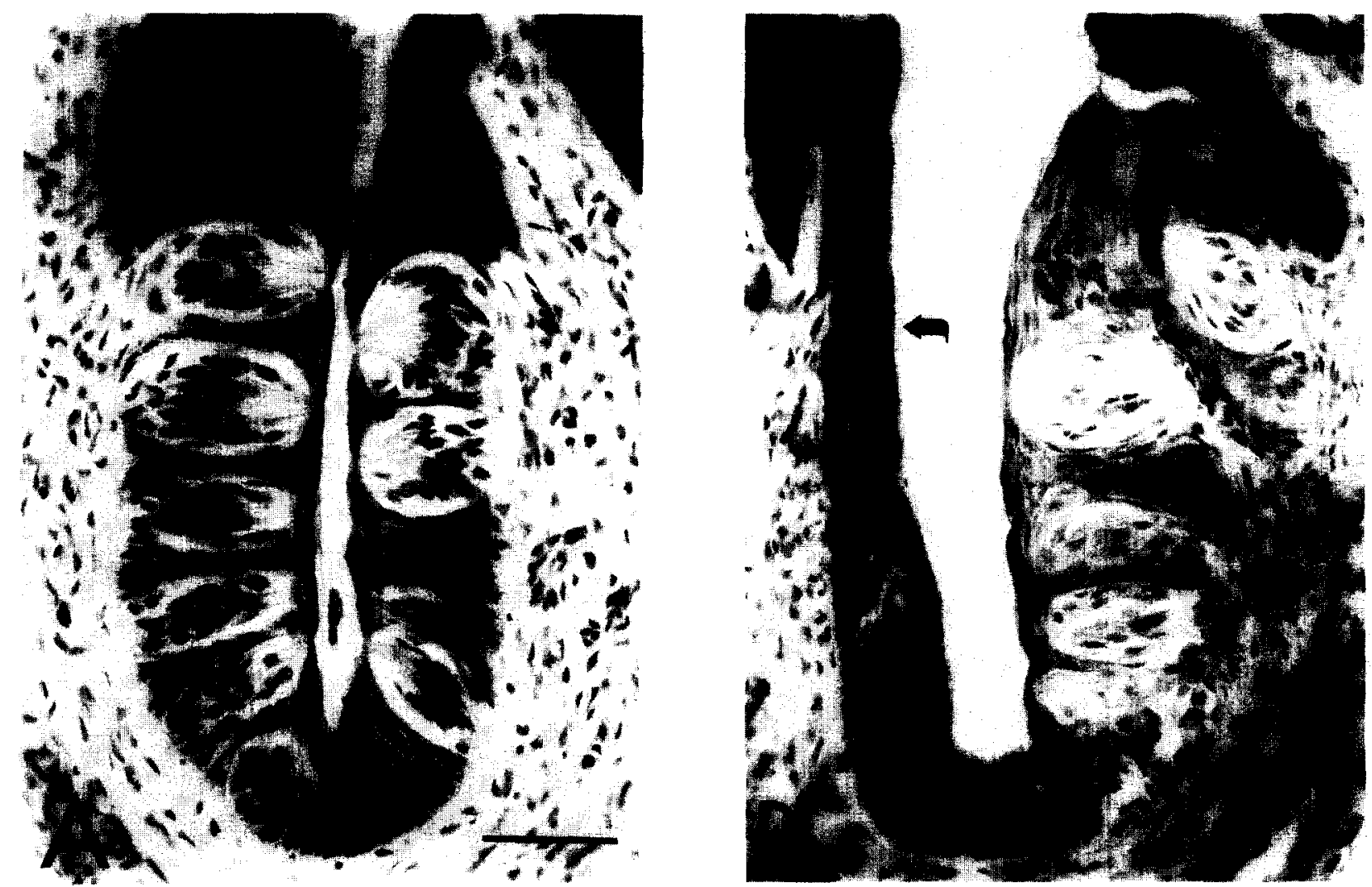

Fig. 2. A: about 10 of 207 taste buds are evident in this section of the left trench of a control vallate papilla examined on day 185 . Innervation was supplied by the CT nerve after crush of one IXth nerve on day 3 and avulsion of the other on day 75 (AV75/CT-CR3). During the sensitive developmental period, the vallate papilla had been continuously innervated by an intact IXth nerve. B: in contrast, after temporary neonatal denervation in experimental animals (AV3/CT-CR3), the vallate papilla was characterized by fewer taste buds and stretches of thinner epithelium where there were no taste buds, e.g. arrow. $10-\mu \mathrm{m}$ transverse paraffin sections stained by Heidenhain's iron hematoxylin method. Bar, $50 \mu \mathrm{m}$ for $\mathrm{A}$ and $\mathrm{B}$.

tongue. Neither 57 nor 66 differs significantly from the $63 \pm 6$ fungiform taste buds supported by IXth nerves crushed on day 75 (groups $6-8$ in Table II; $P>0.05$ ).

\section{DISCUSSION}

\section{The competence of the gustatory epithelium}

At every age a prompt outcome of denervation of the vallate papilla is the loss of all vallate taste buds $^{5,6.11}$. In adults such denervation-triggered taste bud losses can be readily reversed, e.g. regeneration of a IXth nerve crushed on day 75 led to the re-formation of 405 vallate taste buds (AV75/CR75) ${ }^{5}$. However, after the same operation during the neonatal sensitive period (AV3/CR3), the adult IXth nerve came to support just 48 taste buds. The CT was more effective than AV3/CR3 nerves in reducing the shortage of vallate taste buds only if the $C T$ invaded a vallate papilla that had developed with an intact contralateral IXth nerve. Thus, whether gustatory axons will support taste buds depends upon the developmental competence of the gustatory epithelium which in turn depends upon continual neonatal innervation of the vallate epithelium.

\section{The inductive capacities of CR3 IXth nerves}

In development it is known that by day 317 vallate taste buds are normally mature ${ }^{4}$, that these taste buds rapidly disappear after $\mathrm{AV} 3 / \mathrm{CR} 3$, and that mature taste buds reappear only after day 30 in AV3/CR3 rats $^{5}$. In the present experiment such taste buds accumulated to a mean of 48 taste buds after $6-9$ months. Although these observations are consistent with CR3 induction of new taste buds in late post-natal development ${ }^{4.5}$, the progressive trophic activation of previously induced taste cells cannot be ruled out.

\section{The neurotrophic capacities of CR3 IXth nerves}

In adults, 183 of the vallate taste buds that had developed in conjunction with a normal nerve could be supported by the CR3 nerve (AV75/CR3). Nearly as many taste buds were supported by a CR3 nerve that regenerated twice (AV75/CR3-CR3; 173 taste buds). These numbers are only slightly less than the number of taste buds supported by one normal IXth nerve (AV3/NORMAL; 228 taste buds) $^{6}$. It would seem that CR3 nerves have significant neurotrophic capacity. Of course, it is conceivable that the more abnormal vallate 
environment produced by the experimental combination of avulsion of one IXth nerve and crush of the other (AV3/CR3) might lessen the CR3 axons' trophic capacity. However, as assessed by support of fungiform taste buds, the neurotrophic capacity of experimental CR3 nerves was not significantly different from that of control CR 3 nerves (group 6 vs. 7 and $8 ; P>0.05$ ).

The present experiments demonstrate that neither the survival nor the trophic potency of taste axons depends absolutely upon post natal tissue interactions. Nonetheless, given that early epithelial interactions are required to prevent the death of sensory neurons in cranial ganglia in chick embryos ${ }^{18}$, it is certainly possible that taste neuron survival may depend critically upon prenatal neuronal-epithelial interactions.

\section{Cell dynamics associated with taste buds}

In the adult vallate papilla, taste receptor cells are neurotrophically dependent upon gustatory innervation $^{6.12}$. Even with trophic support most taste receptor cells live for $<2 \mathrm{wk}$, owing to the normal turnover of epithelial cells, including vallate taste cells ${ }^{2.7}$. It is believed that the ongoing division of specialized basal cells - taste bud stem cells - generates the young cells that replace aged taste cells ${ }^{13,14}$. After an operation to encourage CT axons to invade the vallate papilla, the pace of axon outgrowth (about $2 \mathrm{~mm} /$ day) ensured at least a $2-3-w k$ period of vallate denervation ${ }^{1,6}$. Since all vallate taste buds degenerate within 1 wk after denervation $^{5,8}$, few denervated mature taste receptor cells would survive for $2-3 \mathrm{wk}$. Instead, the cross-innervated vallate papilla must be re-populated by new taste cells derived from emerging or surviving stem cells. The present results have shown that the neonatally denervated vallate epithelium formed few taste buds, owing to the permanent loss of vallate gustatory competence. Presumably, after limited innervation during the sensitive period, only a few stem cells were committed to a gustatory fate $e^{6.13,14}$. During normal development, taste axons probably induce a large permanent population of gustatory stem cells from precursors $^{5,13,14}$.

\section{Summary and conclusions}

This study examined some of the developmental neuronal-epithelial interactions required to establish mammalian taste buds. It was already known that few vallate taste buds will develop after temporary neonatal denervation of the vallate papilla. The present experiments tested whether this taste bud shortage could be attributed to deficiencies in the taste axons or deficiencies in the taste epithelium. Crushing one IXth nerve in neonates failed to prevent that nerve from supporting numerous vallate and fungiform taste buds in adults. This indicates that taste neurons survived nerve crushing and retained much of their neurotrophic capacity. In contrast, after the neonatal vallate was temporarily denervated by both crushing one IXth nerve and avulsing the other, neither the adult CT nor the adult IXth nerve supported many vallate taste buds. It was concluded that the vallate papilla's gustatory competence had been permanently reduced by temporary neonatal denervation. Evidently gustatory innervation is a critical environmental influence whose actions on neonatal gustatory tissue are required to establish the cell lineage leading to mature taste receptor cells ${ }^{19}$. In the absence of timely innervation during development the precursors of taste cells probably die or irreversibly adopt a non-gustatory fate ${ }^{14,15}$.

Acknowledgements. I thank L.H. Wu for valuable assistance. Supported in part by NIH Grant DCO0083.

\section{REFERENCES}

1 Cheal, M.L. and Oakley, B., Regeneration of fungiform taste buds: temporal and spatial characteristics, J. Comp. Neurol., 172 (1977) 609-626.

2 Farbman, A.I., Renewal of taste bud cells in rat circumvallate papillae, Cell. Tiss. Kinet., 13 (1980) 349-357.

3 Farbman, A.I. and Mbiene, J.-P., Early development and innervation of taste bud-bearing papillae on the rat tongue, $J$. Comp. Neurol, 304 (1991) 172-186.

4 Hosley, M.A. and Oakley, B., Development of the vallate papilla and taste buds in rats, Anat. Rec., 218 (1987) 216-222.

5 Hosley, M.A., Hughes, S.E. and Oakley, B., Neural induction of taste buds, J. Comp. Neurol, 260 (1987) 224-232.

6 Hosley, M.A., Hughes, S.E., Morton, L.L. and Oakley, B., A sensitive period for the neural induction of taste buds, J. Neurosci., 7 (1987) 2075-2080.

7 Hume, W.J., Stem cells in oral epithelid. In C.S. Potten (Ed.), Stem Cells: Their Identification and Characterisation. Churchill Livingston, New York, 1983, pp. 233-270.

8 Kennedy, J.G., The effects of transection of the glossopharyngeal nerve on the taste buds of the circumvallate papilla of the rat. Arch. Oral Biol., 17 (1974) 1197-1207.

9 Miller Jr., I.J. and Smith, D.V., Proliferation of taste buds in the foliate and vallate papillae of postnatal hamsters, Growth Del: Aging, 52 (1988) 123-131.

10 Oakley, B., Altered temperature and taste responses from crossregenerated sensory nerves in the rat's tongue, J. Physiol. 188 (1967) $353-371$.

11 Oakley, B., Trophic competence in mammalian gustation. In D Pfaff (Ed.), Olfactory and Gustatory Influences on the Central Nerious System, Rockefeller University Press, New York, 1985. pp. $92-103$.

12 Oakley, B., On the neurotrophic support of sensory receptor cells. In K.B. Doving (Ed.), Olfaction and Taste X, GCS Press. Oslo, 1990, pp. 186-195.

13 Oakley, B., Neural-epithelial interactions in taste bud regeneration. In J. Whelan (Ed.), Regeneration of Vertebrate Sensory Receptor Cells, Ciba Foundation Symposium, London, in press.

14 Oakley, B., Control mechanisms in taste bud development. In S.A. Simon and S.D. Roper (Eds.), Mechanisms of Taste Transduction, CRC Press, in press.

15 Oakley, B., Wu, L.H., Lawton, A. and DeSibour, C., Neural control of ectopic filiform spines in adult tongue, Neuroscience. 36 (1990) $831-838$. 
16 Oakley, B., Labelle, D.E., Riley, R.A., Wilson, K. and Wu, L.H. The rate and locus of development of rat vallate taste buds. Det: Brain Res.. 58 (1991) 215-221.

17 Rehmer, H., Die Entwicklung der Papilla Vallata und der Anzahl ihrer Geschmacksknospen beim Goldhamster (Mesocricetus auratus Waterhouse, 1839), Anat. Anz., 125 (1969) 274-288.
I8 Vogel, K.S. and Davies, A.M., The duration of neurotrophic factor independence in early sensory neurons is matched to the time course of target field innervation, Neuron, 7 (1991) 819-830. 19 Williams, R.W. and Goldowitz, D.. Lineage versus environment in embryonic retina: a revisionist perspective. Trends Neturosci. 15 (1992) $368-373$ 